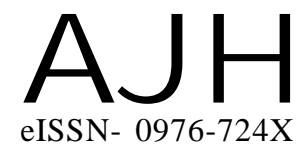

Article history :

Received : 22.08.2017

Revised : 03.11.2017

Accepted : 10.11 .2017
Members of the Research Forum

Associated Authors:

${ }^{1}$ Department of Horticulture, Faculty

of Agriculture, Annamalai

University, ANNAMALAINAGAR

(T.N.) INDIA

Email : kiransharaj@gmail.com
Author for correspondence : ASWATHY SURESH

Department of Horticulture, Faculty of Agriculture, Annamalai

University, ANNAMALAINAGAR

(T.N.) INDIA

Email : ponnumkm@gmail.com
THEASIAN JOURNALOF HORTICULTURE

Volume 12 | Issue 2 | December, 2017 | 189-192

Visit us -www.researchjournal.co.in

RESEARCH PAPER

DOI : 10.15740/HAS/TAJH/12.2/189-192

\section{Influence of time and intensity of pruning on quality of guava (Psidium guajava L.) cv. LUCKNOW 49}

\section{ASWATHY SURESH AND ARUMUGAM SHAKILA ${ }^{\mathbf{1}}$}

ABSTRACT : The present investigation on influence of time and intensity of pruning on quality of guava (Psidium guajava L.) cv. LUCKNOW 49 was conducted at the orchard of the Department of Horticulture, Annamalai University, Tamil Nadu. Five years old guava trees of the cultivar Lucknow 49 were taken for this investigation. Different pruning levels and time of pruning viz., pruning $10 \mathrm{~cm}, 20 \mathrm{~cm}, 30 \mathrm{~cm}$ of apical shoots during mid March, mid April, mid May comprised the treatment combinations. The effect of different treatments were evaluated based on their influence on the quality attributes viz., TSS, ascorbic acid content, acidity, total sugar content. Among the various pruning treatments, it was observed that pruning $30 \mathrm{~cm}$ of apical shoots during mid March proved to be the best in increasing the quality of fruits followed by $20 \mathrm{~cm}$ level of pruning during mid March. The results of the present study indicate that the effect of various pruning treatments on the quality of guava cv. LUCKNOW 49 was more pronounced in season II when compared to season I.

KEY WORDS : Pruning, Pruning intensities, Quality attributes

HOW TO CITE THIS ARTICLE : Suresh, Aswathy and Shakila, Arumugam (2017). Influence of time and intensity of pruning on quality of guava (Psidium guajava L.) cv. LUCKNOW 49. Asian J. Hort., 12(2) : 189-192, DOI : 10.15740/HAS/TAJH/12.2/189-192. 